\title{
Hypokalemic Periodic Paralysis that Presented with Hemiparesis after Dexamethasone Injection
}

\author{
Deksametazon Enjeksiyonu Sonrası Hemiparezi ile Başvuran Hipokalemik \\ Periyodik Paralizi
}

\author{
Özdem Ertürk ${ }^{1}$, Can Özlü² \\ 1Denizli State Hospital, Clinic of Neurology, Denizli, Turkey \\ 2Bozyaka Training and Research Hospital, Clinic of Internal Medicine, İzmir, Turkey
}

Keywords: Hypokalemic periodic paralysis, corticosteroid, hemiparesis

Anahtar Kelimeler: Hipokalemik periyodik paralizi, kortikosteroid, hemiparezi

\section{Introduction}

Hypokalemic periodic paralysis (hypoPP), is a rare, heterogeneous disease with sudden-onset episodic muscular weakness attacks. Besides its genetic forms, it may occur secondary to drugs or endocrine diseases (1). In hypoPP, muscular weakness generally occurs in all four extremities (2). Presentation with hemiparesis or asymmetric involvement is rare. Although corticosteroids have also been reported to induce attacks, there are few published cases in the literature $(2,3)$. We report a patient who presented with left-sided hemiparesis after dexamethasone injection and was diagnosed as having hypoPP.

A man aged 26 years presented to the emergency department with symptoms of weakness in the left arm and leg. Six hours before presentation, he received an $8-\mathrm{mg}$ intramuscular dexamethasone injection and this had been the first dose. He denied any comorbidity or drug use. Family history was unrevealing. There was no history of a similar previous attack. In his neurologic examination, he was conscious, cooperative, oriented, cranial nerve examinations were normal, and there was no facial asymmetry. Muscle strength was $3 / 5$ in proximal and distal muscles of the left upper extremity, $2 / 5$ in proximal and distal muscles of the left lower extremity, and normal on the right side. Plantar reflex was bilaterally flexor. Cranial imaging was normal and his potassium level was $2.1 \mathrm{mmol} / \mathrm{L}$. Free T3, free T4, and thyroid-stimulating hormone levels were within normal limits. No electrocardiogram change was observed. After potassium levels returned to normal levels $(3.9 \mathrm{mmol} / \mathrm{L}$ ) with intravenous potassium replacement, muscular weakness resolved completely. During his 6-months follow-up, corticosteroid was discontinued, hypopotassemia was not observed, and the attacks did not recur.

Attacks of hypoPP may be spontaneous or may be due to a secondary cause. Although rare, drugs may also induce hypoPP $(1,3,4,5)$. In our case, the hypoPP attack was thought to have been induced by corticosteroid use. Drugs that can induce hypoPP include beta mimetics, insulin, corticosteroids, and diuretics $(3,4)$. There are case reports in the literature about hypoPP attacks induced by corticosteroids. Arzel-Hezode et al. (3) reported 12 patients who used intravenous or oral methylprednisolone (16 mg-120 mg doses) or prednisolone (60-80 mg doses). The attacks were triggered even with small doses and severity of the attacks were not found related with dose and route of application. Although a single and low dose of dexamethasone was applied in our patient, it induced a hypoPP attack. The mechanism of hypoPP by corticosteroids has not been clearly defined but it may be due to the Na-K pump in skeletal muscle or due to its insulin or glucose increasing effect (3).

Although muscle weakness is usually generalized in hypoPP, it may also be focal (4); if focal, it is generally found in the muscle group last used (4).

\footnotetext{
Address for Correspondence/Yazışma Adresi: Özdem Ertürk MD, Denizli State Hospital, Clinic of Neurology, Denizli, Turkey Phone: +90 5069124706 E-mail: ozdemerturk@yahoo.com

Received/Geliş Tarihi: 09.03.2016 Accepted/Kabul Tarihi: 23.04 .2016

(C) Turkish Journal of Neurology, Published by Galenos Publishing House.

This article is distributed under the terms of the "Creative Commons Attribution NonCommercial 4.0 International Licence (CC BY-NC 4.0)".
} 
When the picture is not totally settled, paraplegia may be prominent (2). However, hemiparesis is rare. In cases of hypoPP due to corticosteroid use, most attacks are in the form of quadriplegia and there are limited cases of paraplegia (3). In a case series, although quadriplegia was reported in all cases, some cases with atypical initiation (weakness in neck muscles, fallen fingers and fallen leg) were also observed (5). Hemiparesis, as in our case, is an unusual presentation and is important because it may be confused with cerebrovascular diseases on admission to the emergency department. Sparing of facial muscles and flexor plantar responses are helpful in making a differential diagnosis from a central pathology.

Although rare, hypoPP may be detected during evaluation for acute-onset muscle weakness in the emergency department; therefore, it should be kept in mind during differential diagnosis. Acute hemiparesis implies cerebrovascular disease; however, it should be noted that although rare, periodic paralysis may also present in this way.

\section{Etbics}

Informed Consent: Consent form was filled out by all participants. Peer-review: Internal peer-reviewed.

\section{Autborship Contributions}

Surgical and Medical Practices: Özdem Ertürk, Can Özlü, Concept: Özdem Ertürk, Design: Özdem Ertürk, Can Özlü, Data Collection or Processing: Özdem Ertürk, Analysis or Interpretation: Özdem Ertürk, Can Özlü, Literature Search: Özdem Ertürk, Caz Özlü, Writing: Özdem Ertürk.

Conflict of Interest: No conflict of interest was declared by the authors. Financial Disclosure: The authors declared that this study has received no financial support.

\section{References}

1. Finsterer J. Primary periodic paralyses. Acta Neurol Scand 2008;117:145158.

2. Fontaine B, Fournier E, Sternberg D, Vicart S, Tabti N. Hypokalemic periodic paralysis: a model for a clinical and research approach to a rare disorder. Neurotherapeutics 2007;4:225-232.

3. Arzel-Hezode M, McGoey S, Sternberg D, Vicart S, Eymard B, Fontaine B. Glucocorticoids may trigger attacks in several types of periodic paralysis. Neuromuscul Disord 2009;19:217-219.

4. Venance SL, Cannon SC, Fialho D, Fontaine B, Hanna MG, Ptacek LJ, TristaniFirouzi M, Tawil R, Griggs RC, investigators $C$. The primary periodic paralyses: diagnosis, pathogenesis and treatment. Brain 2006;129:8-17.

5. Kayal AK, Goswami M, Das M, Jain R. Clinical and biochemical spectrum of hypokalemic paralysis in North: East India. Ann Indian Acad Neurol 2013;16:211-217 